\title{
Risk factors for nosocomial carbapenem-resistant Klebsiella infections
}

\author{
Nozokomiyal karbapenem dirençli klebsiella enfeksiyonlarında \\ risk faktörlerinin incelenmesi
}

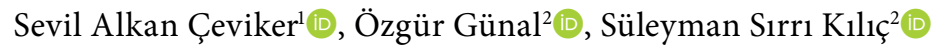 \\ ${ }^{1}$ Department of Infectious Diseases and Clinical Microbiology, University of Health Sciences, \\ Evliya Çelebi Training and Research Hospital, Kütahya, Turkey \\ ${ }^{2}$ Department of Infectious Diseases and Clinical Microbiology, University of Health Sciences, \\ Samsun Training and Research Hospital, Samsun, Turkey
}

\begin{abstract}
Objectives: This retrospective case-control study aims to evaluate the clinical outcomes of patients diagnosed with nosocomial carbapenem-resistant Klebsiella infection (CRK), identify risk factors of this infection, and determine mortality rate.

Patients and methods: The study group consisted of 54 patients ( 23 males, 31 females; mean age $53.05 \pm 11.3$ years, range, 18 to 82 years) diagnosed with CRK infection between January 2014 - July 2018. The control group was randomly selected among patients matched for gender who were hospitalized within the same period ( \pm 15 days) and had nosocomial infection but without CRK growth in cultures.

Results: Nosocomial CRK infection was most prevalent among the intensive care unit (90.75\%). Mechanical ventilation, tracheostomy, presence of nasogastric tube, central venous catheter, elderly age ( $\geq 65$ years), $\mathrm{H} 2$ receptor antagonist treatment, total parenteral nutrition, hospitalization within the past six months, antibiotic use within three months prior to CRK infection, and use of more than two antibiotic groups were identified as risk factors for development of CRK infection. Total mortality rate of the patient group was $31.48 \%$.

Conclusion: In order to prevent spread of nosocomial CRK infections, which has gradually narrowing treatment options, there is a need for further prospective multicenter studies on reducing invasive procedures and inappropriate antibiotic use, identifying correctible risk factors, and taking necessary corrective measures.
\end{abstract}

Keywords: Carbapenem-resistant Klebsiella infection, mortality, nosocomial infection, risk factors.

\section{öz}

Amaç: Bu retrospektif olgu-kontrol çalışmasında, nozokomiyal karbapenem dirençli Klebsiella (KDK) enfeksiyonu olan hastaların klinik sonuçlarının değerlendirilmesi ve bu enfeksiyon için risk faktörlerinin saptanması ve mortalite oranının belirlenmesi amaçlandı.

Hastalar ve yöntemler: Ocak 2014 - Temmuz 2018 tarihleri arasında nozokomiyal KDK enfeksiyonu saptanan 54 hasta (23 erkek, 31 kadın; ort. yaş $53.05 \pm 11.3$ yıl; dağılım 18-82 yıl) çalışma grubunu oluşturdu. Kontrol grubu, aynı dönemde ( \pm 15 gün) ve serviste yatışı bulunan, cinsiyet uyumlu, nozokomiyal enfeksiyonu olan ancak alınan kültürlerinde KDK üremesi olmayan hastalardan randomize olarak seçildi.

Bulgular: Nozokomiyal KDK enfeksiyonu en sık (\%90.75) yoğun bakım ünitelerinde idi. Mekanik ventilasyon, trakeostomi, nazogastrik tüp varlığı, santral venöz kateter varlığı, ileri yaş ( $\geq 65 \mathrm{yıl}), \mathrm{H} 2$ reseptör antagonist tedavisi, total parenteral beslenme, son altı ayda hastanede yatış öyküsü, KDK enfeksiyonu öncesi üç aylık dönemde antibiyotik kullanımı, ikiden fazla grup antibiyotik kullanımı KDK enfeksiyonu gelişiminde risk faktörü olarak saptandı. Hasta grubunda toplam mortalite oranı \%31.48 idi.

Sonuç: Tedavi seçenekleri kademeli daralan nozokomiyal KDK enfeksiyonlarının yayılımının önlenmesi, mümkünse invaziv girişimlerin ve uygunsuz antibiyotik kullanımlarının azaltılması, düzeltilebilir risk faktörlerinin saptanması ve gerekli düzeltici önlemlerin alınması konularında ileriye dönük çok merkezli çalışmalara intiyaç duyulmaktadır.

Anahtar sözcükler: Karbapenem dirençli Klebsiella enfeksiyonu, mortalite, nozokomiyal enfeksiyon, risk faktörleri.

Received: August 23, 2019 Accepted: August 27, 2019 Published online: October 31, 2019

Correspondence: Sevil Alkan Çeviker, MD. SBÜ Evliya Çelebi Eğitim ve Araştırma Hastanesi Enfeksiyon Hastalıkları ve Klinik Mikrobiyoloji Kliniği, 43040 Kütahya, Türkiye. Tel: +90 506 - 6873768 e-mail: s-ewil@hotmail.com 
Klebsiella strains are gram-negative microorganisms that may lead to serious clinical manifestations, and may cause infections such as bloodstream infections (BSI), urinary tract infections (UTI), and intraabdominal abscesses especially when hospital-acquired and in immunosuppressive patients. Infections caused by Klebsiella bacteria that produce carbapenemase are occurring more and more frequently with increased carbapenem use, invasive procedures, and number of immunosuppressive patients. Relevance of these infections is gradually increasing worldwide as well as in our country due to rapid spread of resistance, nosocomial outbreaks, limited number of antibiotic treatment options, increased mortality and morbidity rates, and treatment costs. ${ }^{[1,2]}$ While carbapenem resistance of Enterobacteriaceae, in which Klebsiella is a member of, used to be defined as resistance to third generation cephalosporins (ceftriaxone, cefotaxime, ceftazidime), and either doripenem, meropenem or imipenem, the update to guidelines in 2015 added ertapenem resistance to the definition and removed the condition of cephalosporin resistance. ${ }^{[3]}$

One study that investigated carbapenemase types in European countries in 2014 and 2015 reported that carbapenem-resistance Klebsiella spp. identified in our country was endemic for carbapenemases, regional spread for NDM-1 type (New Delhi metallo-beta-lactamase-1) carbapenemases, and nosocomial outbreaks for VIM. ${ }^{[4]}$ This emphasizes the importance of developing strategies to identify risk factors for Klebsiella type bacterial infections, protection, and prevention against nosocomial spread of these microorganisms. This retrospective case-control study aims to evaluate the clinical outcomes, identify risk factors, and determine mortality in patients diagnosed with nosocomial carbapenemresistant Klebsiella (CRK) infection.

\section{PATIENTS AND METHODS}

This study was planned as a retrospective casecontrol study to identify risk factors associated with development of nosocomial CRK infection, and determine mortality in inpatients who were hospitalized between January 2014 - July 2018. The patient group consisted of 54 patients (23 males, 31 females; mean age $53.6 \pm 11.3$ years; range, 18 to 82 years) who had CRK growth in microbiological cultures and were diagnosed with nosocomial infection according to our hospital's Infection Control Committee (ICC) surveillance data. Patients aged $\geq 18$ years were included in the study regardless of admission diagnoses and gender differences. The control group was randomly selected from patients who were hospitalized within the same period ( \pm 15 days), of the same gender, and same nosocomial infection diagnoses as the patient group, but without CRK growth in microbiological cultures. A control patient corresponded to each patient. Patient and control groups were compared according to risk factors and mortality.

In patients who were admitted twice for the same factor, only the first infection episode was included in the study. The study protocol received approval from the Kütahya Evliya Çelebi Training and Research Hospital Ethics Committee (September 11, 2018; TUEK 141-2018 GOKAEK/7-47). Informed written consent was obtained from all study participants. The study was conducted in accordance with the principles of the Declaration of Helsinki.

\section{Potential risk factors}

Hospital database discharge reports, ICC nosocomial infection surveillance forms, microbiological cultures, and antibiogram results of patients who were diagnosed with nosocomial Klebsiella infection according to the hospital's ICC and registered to the National Hospital Infections Surveillance System (Infline) were retrospectively evaluated. Data including admission diagnoses, chronic renal failure, diabetes mellitus, immunosuppression, malignancy, history of cerebrovascular accident, history of surgery, additional disease such as trauma, invasive procedures (Foley catheter, catheter, mechanic ventilation, etc.), hospital length of stay, duration until development of nosocomial infection, antimicrobial treatments before and during nosocomial infection, Charlson comorbidity indexes (Table 1), and mortality were assessed. Collected data was transferred to forms for evaluation.

\section{Microbiological examination}

Identification and antibiotic sensitivity tests of Klebsiella spp. strains grown in cultures 
Table 1. Charlson Comorbidity Index ${ }^{[5]}$

\begin{tabular}{lc}
\hline Comorbidity & Weighted score $^{*}$ \\
\hline $\begin{array}{l}\text { Diabetes mellitus, myocardial infarction, congestive heart failure, peripheral vascular disease, chronic respiratory } \\
\text { disease, dementia, cerebrovascular disease, connective tissue disease, peptic ulcer, mild liver disease }\end{array}$ & 1 \\
$\begin{array}{l}\text { Leukemia/lymphoma, multiple myeloma, hemiplegia, nonmetastatic solid tumor, moderate-severe renal failure, } \\
\text { diabetes mellitus (end organ damage) }\end{array}$ & 2 \\
Moderate-severe liver failure & 3 \\
Metastatic solid tumor; AIDS & 6
\end{tabular}

* Total score was calculated by adding each comorbidity as points. One point is added for every 10 years past the age of 40 (e.g. 50-59 years: 1 point, 60-69 years: 2 points); AIDS: Acquired immune deficiency syndrome.

were done in the microbiology laboratory of our hospital using the VITEK ${ }^{\circledR} 2$ (BioMérieux, Marcy l'Etoile, France) automated system. According to EUCAST (The European Committee on Antimicrobial Susceptibility Testing) minimum inhibitory concentration (MIC) values, years in which infections caused by Klebsiella spp. strains occurred in our hospital were assessed according to recommended MIC values and CRK-suspected strains were taken into reevaluation with E-test. ${ }^{[5]}$

\section{Definitions of infection types}

Nosocomial infections are defined as infections that develop within 48 hours after hospital admittance. The current CDC (Centers for Disease

Table 2. Distribution of carbapenem-resistant Klebsiella spp. growth according to hospital units

\begin{tabular}{lcc}
\hline & $\mathrm{n}$ & $\%$ \\
\hline Intensive care unit & 49 & 90.75 \\
Internal ICU & 19 & 35.19 \\
Surgical ICU 1 & 10 & 18.52 \\
Surgical ICU 2 & 5 & 9.25 \\
Neurology ICU 1 & 4 & 7.42 \\
Emergency ICU & 4 & 7.42 \\
General ICU & 3 & 5.55 \\
Cardiovascular surgery ICU & 2 & 3.70 \\
Neurology ICU 2 & 1 & 1.85 \\
Burn ICU & 1 & 1.85 \\
Non-ICU wards & 5 & 9.25 \\
General surgery & 2 & 3.70 \\
Neurosurgery & 1 & 1.85 \\
Internal medicine & 1 & 1.85 \\
Medical oncology & 1 & 1.85 \\
Total & 54 & 100 \\
\hline
\end{tabular}

ICU: Intensive Care Unit.
Control and Prevention) diagnostic criteria were used for nosocomial infection diagnosis. ${ }^{[6,7]}$

\section{Statistical analysis}

Statistical analysis was performed with the SPSS version 16.0 (SPSS Inc., Chicago, IL, USA) statistical package program. Quantitative data was expressed as mean \pm standard deviation (SD) and categorical data as number (n) and percentage (\%). Pearson chi-square test and Fisher's exact chi-square test methods were used in comparison of groups of categorical variables, while Student's t-test was used for testing continuous variables. All

Table 3. Nosocomial infection type

\begin{tabular}{lcc}
\hline & $\mathrm{n}$ & $\%$ \\
\hline Bloodstream infection & 23 & 42.60 \\
Central venous catheter related BSI & 18 & 33.35 \\
Laboratory-confirmed BSI & 5 & 9.25 \\
UTI & 17 & 31.48 \\
Catheter-related UTI & 13 & 24.06 \\
Symptomatic UTI & 4 & 7.42 \\
Pneumonia & 6 & 11.12 \\
Ventilator-related pneumonia & 4 & 7.42 \\
Clinically diagnosed pneumonia & 1 & 1.85 \\
Non-specific pneumonia & 1 & 1.85 \\
Surgical site infection & & \\
Primary superficial SSI & 5 & 9.25 \\
Primary deep incisional SSI & 3 & 5.55 \\
Other & 2 & 3.70 \\
Decubitus ulcer infection & 1 & 1.85 \\
Burn infection & 1 & 1.85 \\
Soft tissue infection & 1 & 1.85 \\
Total & 54 & 100 \\
\hline BSI: Bloodstream infection; UTI: Urinary tract infection; SSI: Surgical site \\
infection.
\end{tabular}


Table 4. Demographic, microbiological, and clinical data of patient and control groups

\begin{tabular}{|c|c|c|c|c|c|c|c|}
\hline & \multicolumn{3}{|c|}{ Patient group $(\mathrm{n}=54)$} & \multicolumn{3}{|c|}{ Control group $(n=54)$} & \multirow[b]{2}{*}{$p$} \\
\hline & $\mathrm{n}$ & $\%$ & Mean \pm SD & $\mathrm{n}$ & $\%$ & Mean \pm SD & \\
\hline Mean age (year) & & & $53.05 \pm 11.3$ & & & $47.09 \pm 12.18$ & NS \\
\hline $\begin{array}{r}\text { Gender } \\
\text { Male }\end{array}$ & 23 & 42.60 & & 25 & 46.29 & & NS \\
\hline$\geq 65$ age & 16 & 29.63 & & 5 & 9.25 & & $<0.05^{*}$ \\
\hline Infection length* & & & $25.0 \pm 18$ & & & $25.0 \pm 18$ & \\
\hline Hospitalized unit (ICU) & 49 & 90.75 & & 49 & 90.75 & & NS \\
\hline Primary bacteremia & 23 & 42.60 & & 17 & 31.48 & & NS \\
\hline Secondary bacteremia & 8 & 14.81 & & 5 & 9.25 & & NS \\
\hline Hospitalization within past 6 months & 42 & 77.77 & & 13 & 24.07 & & $<0.001^{*}$ \\
\hline Hospitalization within past 3 months & 13 & 24.07 & & 5 & 9.25 & & NS \\
\hline Transfer from another hospital & 3 & 5.55 & & 2 & 3.70 & & NS \\
\hline Nursing home resident & 12 & 22.22 & & 5 & 9.25 & & NS \\
\hline Surgical procedure within past month & 9 & 16.66 & & 2 & 3.70 & & NS \\
\hline Urologic procedure within past 3 months & 3 & 5.55 & & 4 & 7.42 & & NS \\
\hline Blood transfusion & 17 & 31.48 & & 9 & 16.66 & & NS \\
\hline $\mathrm{H} 2$ receptor antagonist use & 38 & 70.37 & & 23 & 42.60 & & $<0.05^{*}$ \\
\hline Mechanical ventilation & 42 & 77.77 & & 27 & 50 & & $<0.05^{*}$ \\
\hline Central venous catheter & 44 & 81.48 & & 28 & 51.85 & & $<0.05^{*}$ \\
\hline Urinary catheter & 49 & 90.74 & & 45 & 83.33 & & NS \\
\hline Peritoneum dialysis catheter & 2 & 3.70 & & 1 & 1.85 & & NS \\
\hline Nasogastric catheter & 16 & 29.63 & & 6 & 11.12 & & $<0.05^{*}$ \\
\hline Tracheostomy & 12 & 22.22 & & 2 & 3.70 & & $<0.05^{*}$ \\
\hline Chest drain & 2 & 3.70 & & 1 & 1.85 & & NS \\
\hline Abdomen drain & 3 & 5.55 & & 2 & 3.70 & & NS \\
\hline Gastrostomy & 3 & 5.55 & & 5 & 9.25 & & NS \\
\hline Total parenteral nutrition & 28 & 51.85 & & 13 & 24.07 & & $<0.05^{*}$ \\
\hline Colostomy & 3 & 5.55 & & 4 & 7.42 & & NS \\
\hline Cystostomy & 2 & 3.70 & & 1 & 1.85 & & NS \\
\hline Nephrostomy & 1 & 1.85 & & 0 & 0 & & NS \\
\hline Endoscopy/colonoscopy & 3 & 5.55 & & 5 & 9.25 & & NS \\
\hline Bronchoscopy & 2 & 3.70 & & 1 & 1.85 & & NS \\
\hline Antibiotic use within 3 months prior to infection & 49 & 90.75 & & 38 & 70.37 & & $<0.05^{*}$ \\
\hline Cephalosporin use & 32 & 59.25 & & 22 & 40.74 & & NS \\
\hline Anti-pseudomonal penicillin use & 16 & 29.62 & & 13 & 24.07 & & NS \\
\hline Quinolone use & 16 & 29.62 & & 8 & 14.81 & & NS \\
\hline Glycopeptide use & 7 & 12.96 & & 4 & 7.42 & & NS \\
\hline Carbapenem use & 12 & 22.22 & & 5 & 9.25 & & NS \\
\hline Anaerobic effective antibiotic use & 13 & 24.07 & & 9 & 16.66 & & NS \\
\hline Use of more than one group antibiotics & 28 & 51.85 & & 23 & 42.60 & & NS \\
\hline Use of more than two groups antibiotics & 12 & 22.22 & & 2 & 3.70 & & $<0.05^{*}$ \\
\hline Antifungal treatment & 4 & 7.42 & & 2 & 3.70 & & NS \\
\hline Mortality (n), (>28 days) & 17 & 31.48 & & 5 & 9.25 & & $<0.05^{*}$ \\
\hline
\end{tabular}

SD: Standard deviation; " Statistically significant; NS: Not Significant, 
significance tests were two-way and $p$ value of less than 0.05 was considered statistically significant in two-way analyses.

\section{RESULTS}

Nosocomial infections that developed in inpatients hospitalized in our hospital's wards between January 2014 and July 2018 were investigated and 54 patients with infection of CRK origin were included in the study, comprising the nosocomial CRK study group. A total of 54 patients who met criteria listed above were included in the control group. Nosocomial CRK infection according to distribution over years is as follows: six cases in 2014, six cases 2015, 21 cases in 2016, 18 cases 2017, and three cases in the first seven months of 2018. Nosocomial CRK infections were most common in intensive care unit (ICU) patients $(90.75 \% ; n=49)$, while the rest were only five inpatients in wards other than the ICU (9.25\%) (Table 2).
According to distribution of nosocomial CRK infections, 23 patients (42.6\%) had BSI and 17 patients (31.48\%) UTI (Table 3). Carbapenemresistant Klebsiella infection growth was present in blood culture in 25 patients (46.29\%), urine in $10(18.51 \%)$, catheter blood in eight (14.81\%), wound in six (11.12\%), tracheal aspirate in four (7.42\%), and sputum in one patient (1.85\%). According to EUCAST MIC values, of the isolated strains, 24 had resistance to only imipenem, 11 decreased susceptibility to imipenem, and 16 resistance to ertapenem, imipenem, and meropenem. Klebsiella spp. strains isolated from three patients were susceptible to meropenem and imipenem and resistant to ertapenem. Isolated Klebsiella strains were generally susceptible to aminoglycosides (amikacin 72\%, gentamicin $57 \%$, tobramycin 32\%). Colistin resistance was found in only one patient. Colistin resistance had not been confirmed or investigated with agar microdilution.

Table 5. Comorbidities of patient and control groups

\begin{tabular}{|c|c|c|c|c|c|}
\hline \multirow[b]{2}{*}{ Comorbidity } & \multicolumn{2}{|c|}{ Patient group $(n=54)$} & \multicolumn{2}{|c|}{ Control group $(n=54)$} & \multirow[b]{2}{*}{$p$} \\
\hline & $\mathrm{n}$ & $\%$ & $\mathrm{n}$ & $\%$ & \\
\hline Diabetes mellitus & 25 & 46.29 & 14 & 25.92 & $<0.05^{*}$ \\
\hline Solid organ malignancy & 5 & 9.25 & 9 & 16.66 & NS \\
\hline Hematologic malignancy & 3 & 5.55 & 4 & 7.42 & NS \\
\hline Chemotherapy/radiotherapy & 8 & 14.81 & 13 & 24.07 & NS \\
\hline Chronic liver failure & 3 & 5.55 & 5 & 9.25 & NS \\
\hline Hypertension & 42 & 77.77 & 38 & 70.37 & NS \\
\hline Chronic heart failure & 16 & 29.62 & 14 & 25.92 & NS \\
\hline Chronic respiratory disease & 12 & 22.22 & 15 & 27.77 & NS \\
\hline Neurologic disease/sequela & 25 & 46.29 & 18 & 33.33 & NS \\
\hline Trauma & 2 & 3.70 & 1 & 1.85 & NS \\
\hline Burn & 1 & 1.85 & 1 & 1.85 & NS \\
\hline Chronic renal failure & 13 & 24.07 & 5 & 9.25 & NS \\
\hline Acute renal failure & 3 & 5.55 & 5 & 9.25 & NS \\
\hline Chronic diarrhea & 8 & 14.81 & 2 & 3.70 & NS \\
\hline Decubitus wound presence & 14 & 25.92 & 12 & 22.22 & NS \\
\hline Hemodialysis & 5 & 9.25 & 5 & 9.25 & NS \\
\hline Immunosuppressive treatment & 3 & 5.55 & 2 & 3.70 & NS \\
\hline Human immunodeficiency virus infection & 0 & 0 & 0 & 0 & NS \\
\hline Organ transplantation & 2 & 3.70 & 1 & 1.85 & NS \\
\hline Steroid use & 8 & 14.81 & 5 & 9.25 & NS \\
\hline Charlson comorbidity index use $\geq 6$ & 39 & 73.9 & 23 & 26.1 & NS \\
\hline
\end{tabular}

" Statistically significant; NS: Not significant. 
According to demographic characteristics of the patients, 31 were female (57.4\%), 23 were male (42.6\%), and mean patient age was $53.05 \pm 11.3$ (18-82) years. According to risk factors for CRK infection: prevalence of $\geq 65$ age $(p=0.007)$, hospitalization within the past six months $(p<0.001), H 2$ receptor antagonist use $(p<0.05)$, mechanical ventilation $(p<0.05)$, central venous catheter presence $(p<0.05)$, nasogastric catheter presence $(p<0.001)$, tracheostomy presence $(p<0.05)$, total parenteral nutrition $(p<0.05)$, antibiotic use within three months before CRK infection $(p<0.05)$, and use of more than two groups antibiotics $(p<0.05)$ were found significantly high (Table 4). All patients who developed CRK infection underwent combination treatment. Six patients developed colistin-induced nephrotoxicity. In the CRK infection group, mortality occurred in 17 patients (31.7\%) in less than 28 days, which was significantly higher compared to the control group.

According to comorbidities of the patient and control groups, diabetes mellitus was significantly more prevalent among the CRK group $(p<0.05)$. Mean Charlson index was calculated as 3.75 \pm 1.95 in the event of nosocomial infection; this value was $4 \pm 1.9$ in the patient group and $3.5 \pm 2.0$ in the control group. There was no statistically significant difference between the groups according to mean Charlson index scores (Table 5).

\section{DISCUSSION}

Klebsiella spp. strains are observed in 3-8\% of all nosocomial bacterial infections, and are most commonly reported to cause urinary tract infection, pneumonia, and primary bacteremia. ${ }^{[8,9]}$ Throughout the study period, a total of 253 patients (199 carbapenem-susceptible, 54 carbapenemresistant) developed nosocomial Klebsiella spp. infection. Carbapenem resistance of these Klebsiella strains that caused these infections was found as $21.3 \%$. However, this rate only reflects the results of patients who developed nosocomial infection. Over the last 10 years, there is an increased number of reports of carbapenem resistance associated with Klebsiella spp. strains in Europe. While resistance rate was 7.3\% according to 2014 data, there is an increased number of reports especially from Greece, Romania, and Italy $(62.3 \%, 32.9 \%$, and $31.5 \%$, respectively).
These CRK strains are often reported to be susceptible to only tigecycline, colistin and/or aminoglycoside groups. ${ }^{[10]}$ One study conducted in our country found that CRK strains were resistant to all antibiotics except for tigecycline and polymyxin. ${ }^{[1]}$ Ozger et al. ${ }^{[10]}$ investigated 434 nosocomial Klebsiella strains and detected ertapenem resistance in 115 of them (26.5\%). Ertapenem resistance was detected in $34.1 \%$ of strains isolated from intensive care, and $10.1 \%$ of strains isolated from other wards. Although there are studies that report carbapenem resistance does not surpass 5\% among Enterobacteria strains, there are also reports that carbapenem resistance of Klebsiella pneumoniae strains have surged from 5 to $20 \%$ within one year. ${ }^{[12,13]}$

The control groups of most studies in the literature on the risk factors of CRK infection consist of patients with carbapenem-susceptible Klebsiella infection. ${ }^{[14-17]}$ To avoid possible bias, the control group of this study was randomly selected among patients without CRK infection.

In recent years, as in the rest of the world, with the increasing number of invasive procedures in our country, CRK strains that can cause various hospital infections have become an important problem with the gradually decreasing treatment options. Both host-related and environmental risk factors that may cause infections, and especially nosocomial endemics, have been described. There is a limited number of studies in the literature about risk factors for nosocomial CRK infection. These studies have stated age and gender were not significant variables. ${ }^{[17]}$ However, one study in our country found that age was a risk factor for CRK infection. ${ }^{[18]}$ While there was no difference according to gender in our study, age of the CRK group was statistically older. We believe this may be attributed to increased comorbidity and hospitalization of elderly patients.

Some studies report that ICU stay increases risk of nosocomial CRK infection by up to 3.36-17.4 times. ${ }^{[19-22]}$ Papadimitriou-Olivgeris et al. ${ }^{[22]}$ reported CRK colonization in $13 \%$ of ICU patients and that ICU patients should be transferred to other wards as soon as possible. The literature also reports CRK colonization developed in $70-75 \%$ of patients who stayed in ICU. ${ }^{[23,24]}$ Kofteridis et al. ${ }^{[23]}$ reported ICU stay was an independent risk factor for CRK infection/ 
colonization. In our study, nosocomial CRK infection was most common among ICU patients $(\mathrm{n}=49 ; 90.7 \%)$ and there was no statistically significant difference between the cases and control groups according to the hospitalization service.

The literature reports many comorbid diseases are risk factors for CRK infection. Foremost, these include: transplantation (organ and stem cell), severe disease, chronic/acute renal failure, neurologic disease, immunosuppressive treatment, and steroid use. ${ }^{[14-17,19-21,25]}$ In our study, chronic renal failure and comorbid diabetes mellitus were found to be risk factors. While one study found systemic steroid use wasn't a risk factor for CRK infection, ${ }^{[26]}$ another study found it was a preventive factor. ${ }^{[23]}$ Our study found immunosuppressive treatment and steroid use as risk factors.

There are studies in the literature that report invasive procedures and medical treatments were especially risk factors for development of CRK infection. Esen and Leblebicioglu ${ }^{[25]}$ conducted a daily point-prevalence study and reported urinary catheter, nasogastric catheter, intubation, tracheostomy, central venous catheter, mechanical ventilation, and emergency surgical procedures significantly increased risk of nosocomial infection. Budak et al. ${ }^{[26]}$ listed use of invasive devices, total parenteral nutrition, and transfusion of blood products as risk factors. Yigit et al. ${ }^{[27]}$ reported history of surgical procedure, urinary catheter, invasive procedures, and prolonged mechanical ventilation were risk factors for CRK development. In a meta-analysis by Liu et al., ${ }^{[20]}$ central venous catheter, tracheostomy, mechanical ventilation, and total parenteral nutrition were listed as interventional risk factors. Hyle et al. ${ }^{[28]}$ reported central venous catheter and Falagas et al. ${ }^{[12]}$ reported tracheostomy and nasogastric catheter use were independent risk factors. Akgul et al. ${ }^{[16]}$ reported tracheostomy, urinary catheter, central venous catheter, nasogastric catheter, total parenteral nutrition, mechanical ventilation procedures, and emergency operation as risk factors and emphasized that it may be caused by insufficient antisepsis, lack of proper timing of surgical prophylaxis administration, and increased complications due to emergency operation. In our study, use of $\mathrm{H} 2$ receptor antagonists, mechanical ventilation, presence of central venous catheter
(CVC), nasogastric catheter, tracheostomy and total parenteral nutrition were determined as risk factors for CRK.

There are studies which report prolonged hospitalization as a risk factor for Klebsiella infection/colonization. ${ }^{[15,16,22,29]}$ Mean infection time of CRK infections in our study was 25.0 (12.75-40.0) days, which was significantly longer compared to the control group.

Many studies in the literature list antibiotic use as a risk factor for CRK infection. ${ }^{[14-17,19,20,22,30]}$ However, there are studies that report the contrary. ${ }^{[25,31,32]}$ Liu et al. ${ }^{[20]}$ reported quinolone, aminoglycoside, carbapenem, glycopeptide, and antipseudomonal penicillin, Falagas et al. ${ }^{[12]}$ and Hussein et al. ${ }^{[14]}$ reported carbapenem, Zhang et al. ${ }^{[29]}$ carbapenem, glycopeptide, and quinolone, Wu et al. ${ }^{[3]}$ carbapenem and glycopeptide, Akgul et al. $^{[16]}$ carbapenem, colistin, piperacillin, and tazobactam, and Dizbay et al. ${ }^{[18]}$ imipenem and cefoperazone use within three months before infection, and Zarakolu et al. ${ }^{[32]}$ reported antibiotic use within three months before infection, especially only imipenem, were risk factors for CRK infections. In our study, correlation between CRK infection and antibiotic use three months prior to infection was also statistically significant. However, there was no statistically significant difference between groups according to antibiotic groups.

The mortality of nosocomial CRK infection ranges from $40-50 \%$ especially in patients who develop bacteremia. ${ }^{[34-37]} \mathrm{A}$ majority of deaths are reported to occur within two weeks of infection onset, and cancer patients have high mortality rates, especially within the first 30 days. $^{[38]}$ McGregor et al. ${ }^{[37]}$ reported that high Charlson comorbidity index was associated with increased infection risk and was an important predictive factor for mortality. Zarakolu et al. ${ }^{[32]}$ indicated that there was no statistical significance in Charlson score, Glasgow Coma Scale (GCS), and Acute Physiology And Chronic Health Evaluation II (APACHE II) scores in patients with CRK infection-related mortality, but that The Simplified Acute Physiology Score (SAPS) II score was significantly higher in both single-variable and multiple variance analyses. Qureshi et al. ${ }^{[38]}$ found 28-day mortality rate as 39\% in patients who developed CRK bacteremia. Combination 
treatment was also reported as an independent protective factor for survival. Tumbarello et al. ${ }^{[39]}$ reported 30-day mortality rate as $41.6 \%$ and reported lower mortality in those who received in vitro effective combination treatment. Viale et al. ${ }^{[40]}$ stated monotherapy increased mortality, while Balkan et al. ${ }^{[41]}$ reported that combination treatments including colistin reduced mortality. In our study, there was no statistically significant difference between the two groups according to Charlson indexes. Twenty-eight-day mortality was $31.4 \%$ in patients who developed CRK infection, and there was no significant difference between the two groups.

Prevention and nosocomial spread of CRK infections, which are difficult to manage and costly, should be prevented. Following CDC guidelines, ${ }^{[3]}$ standard measures, hand-washing hygiene, surveillance, contact isolation, environmental cleaning and disinfection, quarantine and/or cohort of patients with CRK infection/colonization, separating these patients from caregivers, restricting patient admission to the unit with infection if necessary, and antibiotic management measures are recommended.

\section{Study limitations}

The retrospective study design, and the fact that records accessed from the database was already evaluated were among the limitations of the study. Carbapenem resistance was only evaluated with VITEK and E-test when necessary and was not confirmed with molecular methods.

\section{Conclusion}

In order to prevent spread of nosocomial CRK infections, which has gradually narrowing treatment options, there is a need for further prospective multicenter studies on reducing invasive procedures and inappropriate antibiotic use, identifying correctible risk factors, and taking necessary corrective measures.

\section{Declaration of conflicting interests}

The authors declared no conflicts of interest with respect to the authorship and/or publication of this article.

\section{Funding}

The authors received no financial support for the research and/or authorship of this article.

\section{REFERENCES}

1. Nordmann P, Gniadkowski M, Giske CG, Poirel L, Woodford N, Miriagou V. Identification and screening of carbapenemase-producing Enterobacteriaceae. Clin Microbiol Infect 2012;18:432-8.

2. Nordmann P, Naas T, Poirel L. Global spread of Carbapenemase-producing Enterobacteriaceae. Emerg Infect Dis 2011;17:1791-8.

3. Centers for Disease Control and Prevention. Facility guidance for control of carbapenemresistant Enterobacteriaceae (CRE), November 2015 update - CRE Toolkit. Atlanta (GA): United States Department of Health and Human Services; 2015 Nov. Available at: http://www.cdc.gov/hai/pdfs/cre/ CRE-guidance-508.pdf [Accessed: August 2018, 20].

4. Albiger B, Glasner C, Struelens MJ, Grundmann $\mathrm{H}$, Monnet DL. Carbapenemase-producing Enterobacteriaceae in Europe: assessment by national experts from 38 countries, May 2015. Euro Surveill 2015;20.

5. Leclercq R, Cantón R, Brown DF, Giske CG, Heisig $P$, MacGowan AP, et al. EUCAST expert rules in antimicrobial susceptibility testing. Clin Microbiol Infect 2013;19:141-60.

6. Balkan İi, Mete B, Öztürk R. Primer kan dolaşımı infeksiyonu ve ventilatörle ilişkili pnömoni olgu tanımlarında güncellemeler, derleme. Yoğun Bakım Derg 2013;11:45-55.

7. Schaberg DR, Culver DH, Gaynes RP. Major trends in the microbial etiology of nosocomial infection. Am J Med 1991;91:72-5.

8. Weist K, Högberg LD. ECDC publishes 2015 surveillance data on antimicrobial resistance and antimicrobial consumption in Europe. Euro Surveill 2016;21.

9. Us E, Tekeli A, Arikan Akan O, Dolapci I, Sahin F, Karahan ZC. Molecular epidemiology of carbapenemresistant Klebsiella pneumoniae strains isolated between 2004-2007 in Ankara University Hospital, Turkey. [Article in Turkish] Mikrobiyol Bul 2010;44:1-10.

10. Özger HS, Karaşahin Ö, Telli G, Gaygisız G, Civil F, Dizbay M. Nozokomiyal Klebsiella türleri arasında karbapenem direnç sıklığı ve fenotipik yöntemlerle direncin değerlendirilmesi. Flora Derg 2012;17:103-10.

11. Leblebicioglu H, Cakir N, Celen M, Kurt H, Baris $\mathrm{H}$, Laeuffer J. Comparative activity of carbapenem testing (the COMPACT study) in Turkey. BMC Infect Dis $2012 ; 12: 42$.

12. Falagas ME, Rafailidis PI, Kofteridis D, Virtzili S, Chelvatzoglou FC, Papaioannou V, et al. Risk factors of carbapenem-resistant Klebsiella pneumoniae infections: a matched case control study. J Antimicrob Chemother 2007;60:1124-30.

13. Gasink LB, Edelstein PH, Lautenbach E, Synnestvedt M, Fishman NO. Risk factors and clinical impact of Klebsiella pneumoniae carbapenemase-producing K. pneumoniae. Infect Control Hosp Epidemiol 2009;30:1180-5. 
14. Hussein K, Sprecher H, Mashiach T, Oren I, Kassis I, Finkelstein R. Carbapenem resistance among Klebsiella pneumoniae isolates: risk factors, molecular characteristics, and susceptibility patterns. Infect Control Hosp Epidemiol 2009;30:666-71.

15. Patel G, Huprikar S, Factor SH, Jenkins SG, Calfee DP. Outcomes of carbapenem-resistant Klebsiella pneumoniae infection and the impact of antimicrobial and adjunctive therapies. Infect Control Hosp Epidemiol 2008;29:1099-106.

16. Akgul F, Bozkurt I, Sunbul M, Esen S, Leblebicioglu H. Risk factors and mortality in the Carbapenemresistant Klebsiella pneumoniae infection: case control study. Pathog Glob Health 2016;110:321-5.

17. Schwaber MJ, Klarfeld-Lidji S, Navon-Venezia S, Schwartz D, Leavitt A, Carmeli Y. Predictors of carbapenem-resistant Klebsiella pneumoniae acquisition among hospitalized adults and effect of acquisition on mortality. Antimicrob Agents Chemother 2008;52:1028-33.

18. Dizbay M, Guzel Tunccan O, Karasahin O, Aktas F. Emergence of carbapenem-resistant Klebsiella spp. infections in a Turkish university hospital: epidemiology and risk factors. J Infect Dev Ctries 2014;8:44-9.

19. Eser F, Yılmaz GR, Güner R, Tufan ZK, Güven T, Açıkgöz ZC. Karbapenem dirençli enterobacteriacae enfeksiyonlari: Risk faktörleri. Akd Tip D 2018;4:144-51.

20. Liu P, Li X, Luo M, Xu X, Su K, Chen S, et al. Risk factors for carbapenem-resistant Klebsiella pneumoniae Infection: A Meta-Analysis. Microb Drug Resist 2018;24:190-8.

21. Papadimitriou-Olingeris M, Marangos M, Fligou F, Christofidou M, Bartzavali C, Anastassiou ED, et al. Risk factors for KPC-producing Klebsiella pneumoniae enteric colonization upon ICU admission. J Antimicrob Chemother 2012;67:2976-81.

22. Papadimitriou-Olingeris M, Marangos M, Fligou F, Christofidou M, Sklavou C, Vamvakopoulou S, et al. KPC-producing Klebsiella pneumoniae enteric colonization acquired during intensive care unit stay: the significance of risk factors for its development and its impact on mortality. Diagn Microbiol Infect Dis 2013;77:169-73.

23. Kofteridis DP, Valachis A, Dimopoulou D, Maraki S, Christidou A, Mantadakis E, et al. Risk factors for carbapenem-resistant Klebsiella pneumoniae infection/colonization: a case-case-control study. J Infect Chemother 2014;20:293-7.

24. Bremmer DN, Clancy CJ, Press EG, Almaghrabi $\mathrm{R}$, Chen L, Doi Y, et al. KPC-producing Klebsiella pneumoniae strains that harbor $\mathrm{AAC}\left(6^{\prime}\right)-\mathrm{Ib}$ exhibit intermediate resistance to amikacin. Antimicrob Agents Chemother 2014;58:7597-600.

25. Esen S, Leblebicioglu H. Prevalence of nosocomial infections at intensive care units in Turkey: a multicentre 1-day point prevalence study. Scand J Infect Dis 2004;36:144-8.
26. Budak S, Oncul O, Aktas Z, Acar A, Ozyurt M, Turhan $\mathrm{V}$, et al. The determination of carbapenem resistance in Escherichia coli and Pneumoniae isolates related to nosocomial infections and the evaluation of risk factors. Southeast Asian J Trop Med Public Health 2014;45:113-22.

27. Yigit H, Queenan AM, Anderson GJ, DomenechSanchez A, Biddle JW, Steward CD, et al. Novel carbapenem-hydrolyzing beta-lactamase, KPC-1, from a carbapenem-resistant strain of Klebsiella pneumoniae. Antimicrob Agents Chemother 2001;45:1151-61.

28. Hyle EP, Ferraro MJ, Silver M, Lee H, Hooper DC. Ertapenem-resistant Enterobacteriaceae: risk factors for acquisition and outcomes. Infect Control Hosp Epidemiol 2010;31:1242-9.

29. Zhang Y, Guo LY, Song WQ, Wang Y, Dong F, Liu G. Risk factors for carbapenem-resistant K. pneumoniae bloodstream infection and predictors of mortality in Chinese paediatric patients. BMC Infect Dis 2018;18:248.

30. Debby BD, Ganor O, Yasmin M, David L, Nathan $\mathrm{K}$, Ilana $\mathrm{T}$, et al. Epidemiology of carbapenem resistant Klebsiella pneumoniae colonization in an intensive care unit. Eur $\mathrm{J}$ Clin Microbiol Infect Dis 2012;31:1811-7.

31. Mouloudi E, Protonotariou E, Zagorianou A, Iosifidis E, Karapanagiotou A, Giasnetsova $\mathrm{T}$, et al. Bloodstream infections caused by metallo- $\beta$ lactamase/Klebsiella pneumoniae carbapenemaseproducing $\mathrm{K}$. pneumoniae among intensive care unit patients in Greece: risk factors for infection and impact of type of resistance on outcomes. Infect Control Hosp Epidemiol 2010;31:1250-6.

32. Zarakolu P, Eser OK, Aladag E, Al-Zahrani IA, Day $\mathrm{KM}$, Atmaca O, et al. Epidemiology of carbapenemresistant Klebsiella pneumoniae colonization: a surveillance study at a Turkish university hospital from 2009 to 2013. Diagn Microbiol Infect Dis 2016;85:466-70.

33. Wu D, Cai J, Liu J. Risk factors for the acquisition of nosocomial infection with carbapenem-resistant Klebsiella pneumoniae. South Med J 2011;104:106-10.

34. Qureshi ZA, Paterson DL, Potoski BA, Kilayko MC, Sandovsky G, Sordillo E, et al. Treatment outcome of bacteremia due to KPC-producing Klebsiella pneumoniae: superiority of combination antimicrobial regimens. Antimicrob Agents Chemother 2012;56:2108-13.

35. Zarkotou O, Pournaras S, Tselioti P, Dragoumanos V, Pitiriga V, Ranellou K, et al. Predictors of mortality in patients with bloodstream infections caused by KPC-producing Klebsiella pneumoniae and impact of appropriate antimicrobial treatment. Clin Microbiol Infect 2011;17:1798-803.

36. Wu PF, Chuang C, Su CF, Lin YT, Chan YJ, Wang FD, et al. High minimum inhibitory concentration of imipenem as a predictor of fatal outcome in 
patients with carbapenem non-susceptible Klebsiella pneumoniae. Sci Rep 2016;6:32665.

37. Freire MP, Pierrotti LC, Filho HH, Ibrahim KY, Magri AS, Bonazzi PR, et al. Infection with Klebsiella pneumoniae carbapenemase (KPC)-producing Klebsiella pneumoniae in cancer patients. Eur J Clin Microbiol Infect Dis 2015;34:277-86.

38. McGregor JC, Kim PW, Perencevich EN, Bradham $\mathrm{DD}$, Furuno JP, Kaye KS, et al. Utility of the Chronic Disease Score and Charlson Comorbidity Index as comorbidity measures for use in epidemiologic studies of antibiotic-resistant organisms. Am $\mathrm{J}$ Epidemiol 2005;161:483-93.

39. Tumbarello M, Trecarichi EM, De Rosa FG,
Giannella M, Giacobbe DR, Bassetti M, et al. Infections caused by KPC-producing Klebsiella pneumoniae: differences in therapy and mortality in a multicentre study. J Antimicrob Chemother 2015;70:2133-43.

40. Viale P, Giannella M, Bartoletti M, Tedeschi S, Lewis R. Considerations About Antimicrobial Stewardship in Settings with Epidemic Extended-Spectrum $\beta$-Lactamase-Producing or Carbapenem-Resistant Enterobacteriaceae. Infect Dis Ther 2015;4:65-83.

41. Balkan II, Aygün G, Aydın S, Mutcalı SI, Kara $Z$, Kuşkucu M, et al. Blood stream infections due to OXA-48-like carbapenemase-producing Enterobacteriaceae: treatment and survival. Int $\mathrm{J}$ Infect Dis 2014;26:51-6. 